\title{
Mobile Learning in Higher Education: A Bibliometric Review
}

\author{
https://doi.org/10.3991/ijim.v14i11.13973
}

Sónia Rolland Sobral

REMIT, Universidade Portucalense, Porto, Portugal

sonialuportu.pt

\begin{abstract}
Changing habits leads to changes in ways of learning and teaching. The widespread use of smartphones appears as an opportunity and at the same time as a need for adoption in higher education institutions. The purpose of this paper is to analyze the scientific production on mobile learning in higher education in journals indexed in Clarivate Analytics' Web of Science and Elsevier's Scopus. The sample was composed by 450 articles in total. The results obtained by bibliometric analysis showed that the publication rates continue to increase, in which journals they are published, which are the organizations and countries that publish the most, how the evolution of perspective has changed since 2010 and which are the most cited articles. We concluded that since mobile learning in higher education is a reality, there still seems to be a possibility for evolution in good quality publications.
\end{abstract}

Keywords-Mobile learning; M-Learning; higher education; Bibliometrics; Data analysis

\section{$1 \quad$ Introduction}

The world has changed, habits have changed. Higher education institutions must seize opportunities and at the same time adapt to the way people communicate and use technologies. Smartphones have become ubiquitous these days: people all over the world use those devices to communicate, to read and to study. At the beginning of this century, Chen et al [1] saw an opportunity and a paradigm shift: with the aid of wireless communication technology, educational practice can be embedded into mobile life without wired-based communication. With the trend of educational media becoming more increasingly mobilized, portable and individualized, the learning form is being changed dramatically. According to Wang, Wiesemes and Gibbon [2] 'm-learning' is not just about using or learning how to use a mobile tool. McConatha et al. [3] in 2008 referred to Mobile Learning (M-Learning or MLearnig) as a relatively new tool in the pedagogical arsenal to support students and teachers as they navigate the options available in the expanding world of distance learning. M-Learning is learning accomplished with the use of small, portable computing devices. These computing devices may include: smartphones, personal digital assistants (PDAs) and similar handheld devices. M-learners typically view content and/or lessons in small, manageable formats that can 
be utilized when laptop or fixed station computers are unavailable. In 2011, Alzaza and Yaakub [4] considered m-Learning as the next generation of e-Learning using mobile technologies. Bannan [5] said that Mobile learning has become a recognized sub-domain of technology-enhanced learning.

Baran [6] defines mobile learning using multiple terms "mobility (Sharples et al., 2009), access (Parsons \& Ryu, 2006), immediacy (Kynäslahti, 2003), situativity (Cheon, Lee, Crooks, \& Song, 2012), ubiquity (Kukulska-Hulme et al., 2009), convenience (Kynäslahti, 2003), and contextuality (Kearney, Schuck, Burden, \& Aubusson, 2012)". In 2017, Al-Hunaiyyan, Al-Sharhan and Alhajri [7] defined m-learning as a learning strategy that provides students with the $21^{\text {st }}$ century learning capabilities in order to enable them to utilize a wide range of portable computing devices. These devices are connected via smart classroom network or the Internet to smart components or online interactive educational content and learning resources. This means that you can be connected with a learning environment that is controlled by the teacher (instructor) using the Learning Management System (LMS) or tools of Social Online Learning (SOL) that achieve a collaborative, interactive and innovative learning environment.

However, there continues to be a distinct lack of definitional clarity about mobile learning - conceptualizations may vary greatly but research designs tend to focus on attempts to measure the efficacy of mobile device-based interventions in terms of attainment or achievement gains [4]. Viberg et al [8] argue that in order to fuse informal and formal learning, m-Learning designers need to offer clearer definitions of the concepts "formal" and "informal", considering m-Learning as a part of e-Learning. While mobile phones provide many of the benefits associated with 1:1 computing, they also share some of the same barriers which, according O'Bannon and Thomas [9], could be disruptive and a distraction. Some students use mobile phones for cheating, sexting, and cyberbullying.

Jui-Long Hung and Ke Zhang [10] conducted a study based on 119 journal articles from 2003 to 2008. They found that m-Learning articles increased from 8 in 2003 to 36 in 2008 and that the most popular domain in current was Effectiveness, Evaluation, and Personalized Systems. Wu, Wu, Chen, Kao, Lin and Huang [11] reviewed 164 mobile learning studies from 2003 to 2010. Their major findings include that most studies of mobile learning were focus is on effectiveness, followed by mobile learning system design. Surveys and experiments were used as the primary research methods. Greig Krull and Josep M Duart [12] made a study of 233 articles dated from 2011 to 2015 to identify emerging trends in mobile learning research in higher education. They found that $\mathrm{m}$-Learning in higher education was a growing field as evidenced by the increasing variety of research topics, methods and researchers; the most common research topic was about enabling m-learning applications and systems. Christoph Pimmera, Magdalena Mateescub and Urs Gröhbiela [13] selected 36 studies identified as eligible for review (2000 to 2013) and found that the broad majority of mobile and ubiquitous learning studies showed positive effects. However, empirical evidence that would favour a broad application of mobile and ubiquitous learning in higher education settings is still limited. In addition, the expectation that mobile learning could transform higher education cannot be confirmed because the majority of the reviewed studies followed instructionist paradigms. Qing-KeFu and Gwo-Jen Hwang [14] made a study which reviewed 
the literature on mobile technology-supported collaborative learning from 2007 to 2016. They found that mobile collaborative learning is a rapidly growing research field and that it is important to reinforce the research on the process of learners' knowledge construction as well as their perceptions and behaviors in collaborative learning processes. Sönmez, A.; Göçmez, L.; Uygun, D. \& Ataizi, M. [15] selected 11 studies between 2013 and 2017 to explained mostly used purposes on articles. They concluded that the most popular topics were learners' perceptions of mobile technologies and mlearning and students' acceptance of m-learning. Chiu-Lin Lai [16] review of the top 100 highly cited mobile learning papers mainly focused on comparing the different mobile learning modes to find more effective approaches for conducting mobile learning activities. He concludes that mobile learning places have changed from classrooms to real-world contexts and that the number of across-context studies is increasing.

All of these studies are important to give clues on how research in the area has been carried out and eventually to predict future. This study provides insights not previously identified or evaluated in such detail using bibliometric indicators since the first articles were published until the year 2019. Bibliometric analysis [17] is the quantitative study of bibliographic material: it provides a general picture of a research field that can be classified by papers, authors and journals. Bibliometric methods employ a quantitative approach for the description, evaluation, and monitoring of published research. These methods have the potential to introduce a systematic, transparent, and reproducible review process and thus improve the quality of reviews [18]. Bibliometric analysis provides objective criteria that can assess the research development in a field and act as a valuable tool for measuring scholarship quality and productivity [19]. Bibliometric methods offer systematization and replication processes that can improve understanding of the dissemination of knowledge in a field and can highlight gaps and opportunities that may contribute to the advancement of the discipline [20].

The aim of this study is to conduct a literature review of the Mobile Learning in Higher Education research using bibliometric methods. The next section presents the research questions. The methodology is defined in the third section. Then the results are presented and at the end they are discussed and the conclusion is made.

\section{The Research Question}

The question, along with the purpose of the review, the intended deliverables and the intended audience, determines how the data are identified, collected and presented [21]. There are several questions that we want to answer in this paper:

- How has the evolution of the publication of articles in quality journals related to mobile learning in higher education been?

- What are the characteristics of journals where there is a greater number of publications related to the subject?

- What is the approach to m-Learning in higher education? Has it evolved over the years?

- Who publishes on the subject? 
- Where do researchers who are interested in m-Learning in higher education work? What country do they live in?

- What are the most cited articles? And in the last three years?

\section{$3 \quad$ Methodology}

The term bibliometrics was first used in 1969 by Alan Pritchard, hoping that the term would be used explicitly in all studies which seek to quantify the processes of written communication and would quickly gain acceptance in the field of information science [22]. Moed mentioned the potential of this type of study that reveals the enormous potential of quantitative, bibliometric analyses of the scholarly literature for a deeper understanding of scholarly activity and performance, and highlights their policy relevance. [23] In scientific research, it is important to get a wider perspective of research already being conducted concerning a relevant subject matter [24] and a bibliometric analysis profile on the research trajectory and dynamics of the research activities across the globe [25]. This is a bibliometric study that systematically analyses the literature using articles indexed at Elsevier's Scopus (Scopus) and Clarivate Analytics' Web of Science (WoS) databases. This study conducts a bibliometric analysis of international journal papers that we expect provides a useful reference for future research.

The search strategy was

Title: "mobile learning" OR " $m$-Learning" OR M-Learning

Title-Abstract-keywords: Univers* OR "higher education"

DocType: Article OR Review

PUBYEAR: $<2020$.

\section{$4 \quad$ Results}

A set of 306 published papers were collected from WoS and 441 from SCOPUS. The search returned a total of 450 articles and reviews after discounting the duplicate results. The first article in Scopus was published in 2007 (Fig 1. Annual evolution published papers), when WoS already had 5 articles (1 in 2003, 1 in 2004 and 4 in 2005). The growth of publications rates has increased every year (except for 2011 and 2014): 30 until 2010 (6.6\%), 116 in 2010-2014 (25.8\%) and 304 in 2015-2019 (67.6\%). 


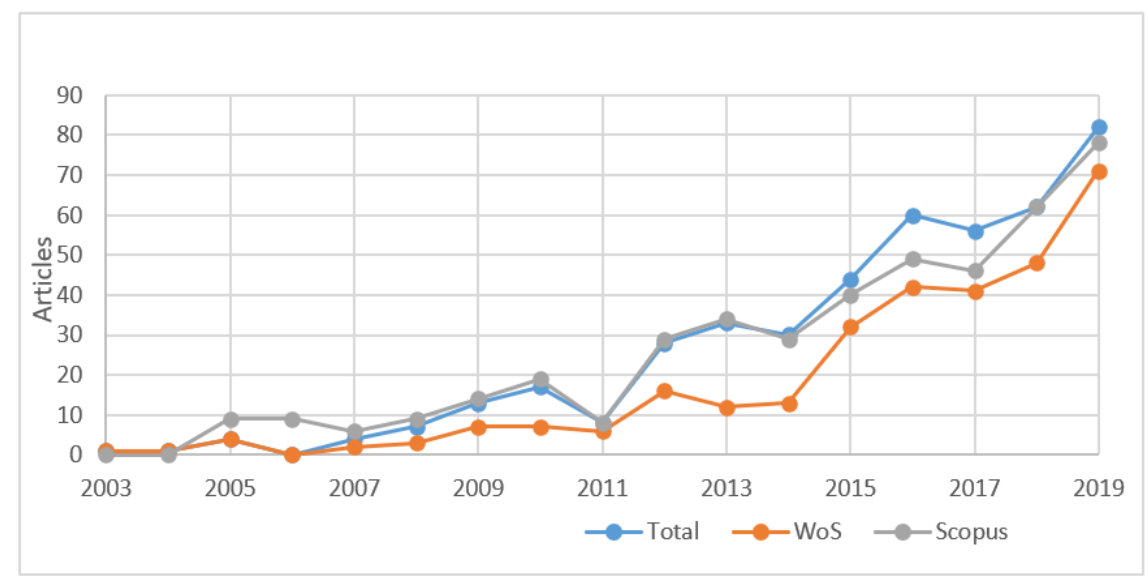

Fig. 1. Annual evolution published papers

Papers were published in 244 international journals, 15 of which published five or more articles (Journals information's.). Two of these journals were cancelled in 2017. International Journal of Mobile Learning and Organisation published 19 articles, International Journal of Interactive Mobile Technologies published 17. Five of those 15 journals were published in United Kingdom and four in the United States. Computers and Education and Computers in Human Behaviour were the journals with best CiteScore 2018 (CiteScore measures average citations received per document published in the serial [6]), respectively 7.72 and 6.14, and best SJR 2018 (SCImago Journal Rank measures weighted citations received by the serial [7]), respectively 2.323 and 1.711 . Computers and Education was the journal with best Source Normalized Impact per Paper (SNIP) 2018. The most common WoS subjects are Social Sciences and Computer Science. The most common WoS categories are Social Sciences (Education) and Social Sciences (E-Learning). Most of those journals are ranked in the first quartile in Journal Citation Reports. 
Table 1. Journals information's.

\begin{tabular}{|c|c|c|c|c|c|c|c|c|c|}
\hline Journal & $\#$ & Country & \begin{tabular}{|c|} 
Cite \\
Score \\
2018
\end{tabular} & $\begin{array}{l}\text { SJR } \\
2018\end{array}$ & $\begin{array}{l}\text { SNIP } \\
2018\end{array}$ & \begin{tabular}{|c|c|} 
Cite \\
Score \\
Tracke \\
r 2019 \\
\end{tabular} & $\begin{array}{l}\text { Wos Subject } \\
\text { (Category) }\end{array}$ & Quart & H Index \\
\hline $\begin{array}{l}\text { International Journal } \\
\text { of Mobile Learning } \\
\text { and Organisation }\end{array}$ & 19 & $\begin{array}{l}\text { Switzer- } \\
\text { land }\end{array}$ & 1.63 & 0.575 & 0.849 & 1.91 & $\begin{array}{l}\text { Computer Science } \\
\text { (Computer Sci- } \\
\text { ence Applica- } \\
\text { tions) Social Sci- } \\
\text { ences (Education; } \\
\text { E-Learning) }\end{array}$ & Q2 & 18 \\
\hline $\begin{array}{l}\text { International Journal } \\
\text { of Interactive Mobile } \\
\text { Technologies }\end{array}$ & 17 & Germany & 1.28 & 0.220 & 0.776 & 1.46 & $\begin{array}{l}\text { Computer Science } \\
\text { (Computer Net- } \\
\text { works and Com- } \\
\text { munications; } \\
\text { Computer Science } \\
\text { Applications) So- } \\
\text { cial Sciences (E- } \\
\text { Learning) }\end{array}$ & Q3 & 8 \\
\hline $\begin{array}{l}\text { International Review } \\
\text { of Research in Open } \\
\text { and Distance Learn- } \\
\text { ing }\end{array}$ & 14 & Canada & 2.87 & 1.202 & 1.774 & 2.78 & $\begin{array}{l}\text { Social Sciences } \\
\text { (Education; E- } \\
\text { Learning) }\end{array}$ & Q1 & 56 \\
\hline $\begin{array}{l}\text { British Journal of Ed- } \\
\text { ucational Technology }\end{array}$ & 9 & $\begin{array}{l}\text { United } \\
\text { Kingdom }\end{array}$ & 4.07 & 1.419 & 2.354 & 4.35 & $\begin{array}{l}\text { Social Sciences } \\
\text { (Education; E- } \\
\text { Learning) }\end{array}$ & Q1 & 81 \\
\hline $\begin{array}{l}\text { Computers and Edu- } \\
\text { cation }\end{array}$ & 9 & $\begin{array}{l}\text { United } \\
\text { Kingdom }\end{array}$ & 7.72 & 2.323 & 3.797 & 8.96 & $\begin{array}{l}\text { Computer Science } \\
\text { (Computer Sci- } \\
\text { ence (miscellane- } \\
\text { ous)) Social Sci- } \\
\text { ences (Education; } \\
\text { E-Learning) }\end{array}$ & Q1 & 149 \\
\hline $\begin{array}{l}\text { Education and Infor- } \\
\text { mation Technologies }\end{array}$ & 9 & $\begin{array}{l}\text { United } \\
\text { States }\end{array}$ & 2.19 & 0.598 & 1.395 & 2.51 & $\begin{array}{l}\text { Social Sciences } \\
\text { (Education; E- } \\
\text { Learning; Library } \\
\text { and Information } \\
\text { Sciences) }\end{array}$ & Q1 & 31 \\
\hline $\begin{array}{l}\text { Turkish Online Jour- } \\
\text { nal of Educational } \\
\text { Technology (can- } \\
\text { celled 2017) }\end{array}$ & 9 & Turkey & $\begin{array}{l}0.32 * \\
(2016 \\
)\end{array}$ & 0.126 & 0.255 & & $\begin{array}{l}\text { Social Sciences } \\
\text { (Education; E- } \\
\text { Learning) }\end{array}$ & Q4 & 28 \\
\hline $\begin{array}{l}\text { International Journal } \\
\text { of Emerging Tech- } \\
\text { nologies in Learning }\end{array}$ & 7 & Germany & 0.97 & 0.219 & 0.819 & 1.24 & \begin{tabular}{|l|} 
Engineering (En- \\
gineering (miscel- \\
laneous)) Social \\
Sciences (Educa- \\
tion; E-Learning)
\end{tabular} & Q2; Q3 & 15 \\
\hline $\begin{array}{l}\text { International Journal } \\
\text { of Mobile and } \\
\text { Blended Learning }\end{array}$ & 7 & $\begin{array}{l}\text { United } \\
\text { States }\end{array}$ & 1.19 & 0.429 & 0.725 & 0.98 & $\begin{array}{l}\text { Computer Science } \\
\text { (Computer Sci- } \\
\text { ence (miscellane- } \\
\text { ous)) Social Sci- } \\
\text { ences (Education; } \\
\text { E-Learning) }\end{array}$ & Q2 & 15 \\
\hline $\begin{array}{l}\text { Advanced Science } \\
\text { Letters (cancelled } \\
\text { 2017) }\end{array}$ & 6 & $\begin{array}{l}\text { United } \\
\text { States }\end{array}$ & $\begin{array}{c}0.21 \\
* \\
(2016 \\
)\end{array}$ & 0.117 & 0.280 & & $\begin{array}{l}\text { Computer Science } \\
\text { (Computer Sci- } \\
\text { ence (miscellane- }\end{array}$ & Q4 & 24 \\
\hline
\end{tabular}




\begin{tabular}{|c|c|c|c|c|c|c|c|c|c|}
\hline & & & & & & & \begin{tabular}{|l|} 
ous)) Energy (En- \\
ergy (miscellane- \\
ous)) Engineering \\
(Engineering \\
(miscellaneous)) \\
Environmental \\
Science (Environ- \\
mental Science \\
(miscellaneous)) \\
Mathematics \\
(Mathematics \\
(miscellane- \\
ous))Social Sci- \\
ences (Education; \\
Health (social sci- \\
ence))
\end{tabular} & & \\
\hline $\begin{array}{l}\text { Australasian Journal } \\
\text { of Educational Tech- } \\
\text { nology }\end{array}$ & 6 & Australia & 2.13 & 0.721 & 1.092 & 2.33 & $\begin{array}{l}\text { Social Sciences } \\
\text { (Education; E- } \\
\text { Learning) }\end{array}$ & Q1 & 40 \\
\hline $\begin{array}{l}\text { Computers in Human } \\
\text { Behavior }\end{array}$ & 6 & $\begin{array}{l}\text { United } \\
\text { Kingdom }\end{array}$ & 6.14 & 1.711 & 2.245 & 7.48 & \begin{tabular}{|l} 
Arts and Humani- \\
ties (Arts and Hu- \\
manities (miscel- \\
laneous)) Com- \\
puter Science \\
(Human-Com- \\
puter Interaction) \\
Psychology (Psy- \\
chology (miscel- \\
laneous))
\end{tabular} & Q1 & 137 \\
\hline $\begin{array}{l}\text { Innovations in Edu- } \\
\text { cation and Teaching } \\
\text { International }\end{array}$ & 5 & $\begin{array}{l}\text { United } \\
\text { Kingdom }\end{array}$ & 1.34 & 0.657 & 0.962 & 1.59 & $\begin{array}{l}\text { Social Sciences } \\
\text { (Education) }\end{array}$ & Q2 & 45 \\
\hline $\begin{array}{l}\text { Journal of Computer } \\
\text { Assisted Learning }\end{array}$ & 5 & $\begin{array}{l}\text { United } \\
\text { Kingdom }\end{array}$ & 4.11 & 1.382 & 2.267 & 3.76 & $\begin{array}{l}\text { Computer Science } \\
\text { (Computer Sci- } \\
\text { ence Applica- } \\
\text { tions) Social Sci- } \\
\text { ences (Education; } \\
\text { E-Learning) } \\
\end{array}$ & Q1 & 80 \\
\hline $\begin{array}{l}\text { Journal of Educa- } \\
\text { tional Computing Re- } \\
\text { search }\end{array}$ & 5 & $\begin{array}{l}\text { United } \\
\text { States }\end{array}$ & 2.04 & 0.789 & 0.992 & 2.57 & $\begin{array}{l}\text { Computer Science } \\
\text { (Computer Sci- } \\
\text { ence Applica- } \\
\text { tions) Social Sci- } \\
\text { ences (Education) }\end{array}$ & Q2; Q1 & 54 \\
\hline
\end{tabular}

In the 450 articles we found 3386 keywords (even through 18 of the articles do not have keywords). Mobile Learning (261), m-Learning (114), e-Learning (88), Higher education (75) and students (58) are the most common keywords Fig 2. Most common keywords). If we consider the papers published until 2010, the production between 2010 and 2014 and the one that dates from 2015 to 2019, and referring to the top 25 most used keywords, we see that there are 17 keywords that are found in the three groups: assessment, Education, Education computing, E-Learning, Engineering education, Higher education, human, Internet, Learning, Learning systems, m-Learning, Mobile devices, Mobile Learning, Research, Students, Teaching and Teaching and learning. There are keywords that are only in the top 25 of production until 2010: Case Study, 
Classroom teaching, Collaborative learning, Computer science, Environmental awareness, Interactivity, Multimedia systems and School buildings. Interestingly, or perhaps not, there are eight keywords found in the two other groups (2010-2014 and 2015-2019) but which do not appear in the top 25 of the keywords of papers until 2010: Computer aided instruction, distance education, mobile technology, Smartphones, Surveys, Technology acceptance model, University students and Learning management systems.

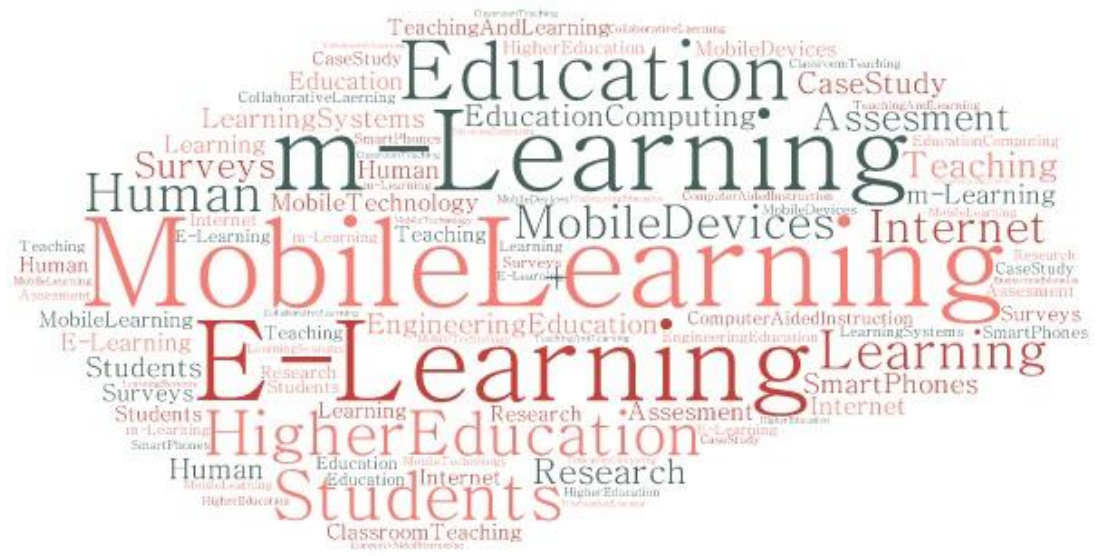

Fig. 2. Most common keywords

$37 \%$ of the articles have two authors and $33 \%$ have three co-authors. One of the articles has ten authors (Fig 3. Number of authors).

There are six authors with five or more articles: MS. Sarrab (8), H. Uzunboylu and M. A. Almaiah (6), H. Al-Shihi, JooYoungJu and M. Al-Emran (5) (Authors with more articles). 
Paper-Mobile Learning in Higher Education: A Bibliometric Review

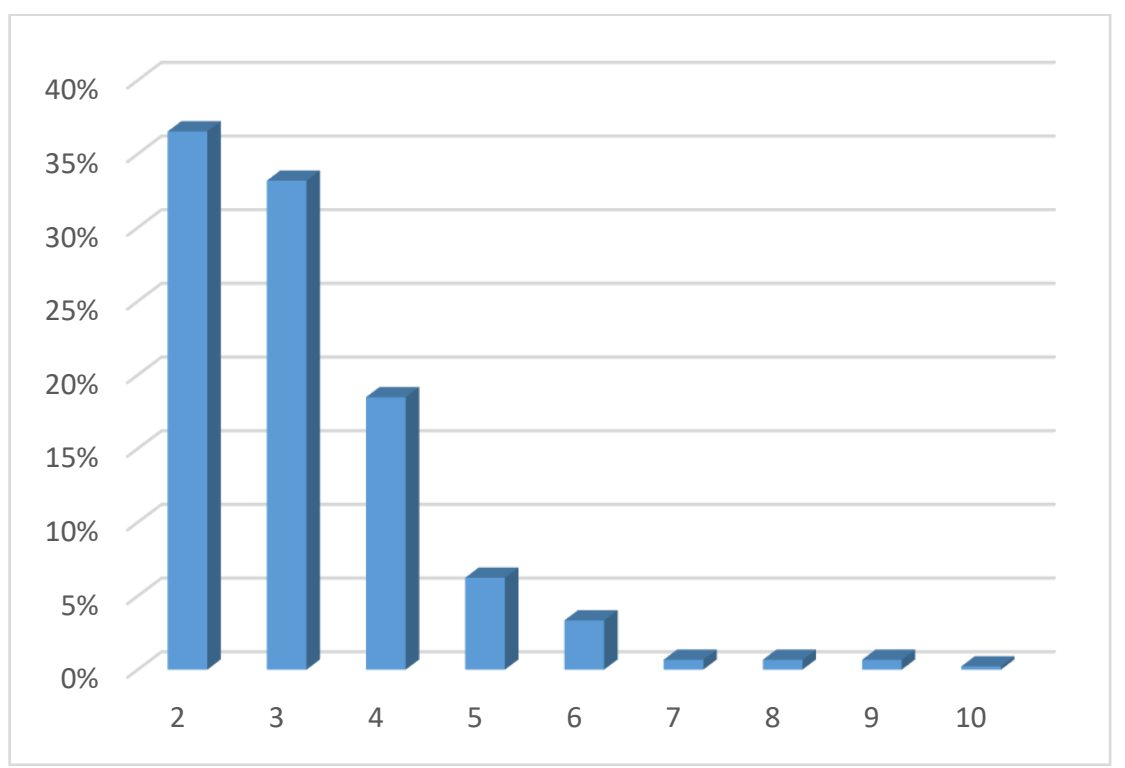

Fig. 3. Number of authors

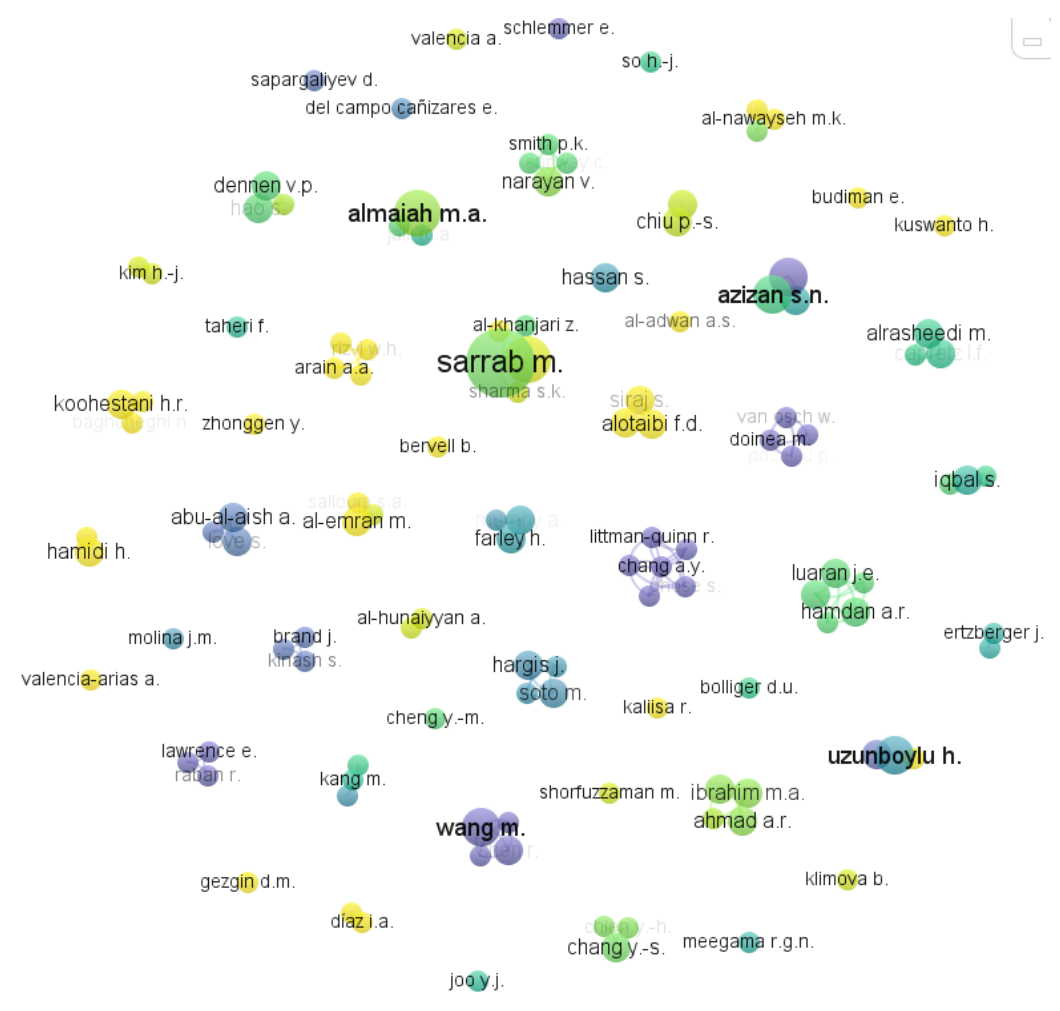

Fig. 4. Network visualization, Authors 
Table 2. Authors with more articles

\begin{tabular}{|l|c|l|}
\hline \multicolumn{1}{|c|}{ Author } & N & \multicolumn{1}{|c|}{ Organization } \\
\hline M. Sarrab & 8 & $\begin{array}{l}\text { Communication and Information Research Center, Sultan Qaboos University, Mus- } \\
\text { cat, Oman }\end{array}$ \\
\hline H. Uzunboylu & 6 & $\begin{array}{l}\text { Department of Computer Education and Instructional Technology, Near East Uni- } \\
\text { versity, Via Mersin 10, North Cyprus, Turkey }\end{array}$ \\
\hline M. A. Almaiah & 6 & King Faisal University, Al-Ahsa, 31982, Saudi Arabia \\
\hline H. Al-Shihi & 5 & $\begin{array}{l}\text { Communication and Information Research Center, Sultan Qaboos University, Mus- } \\
\text { cat, Oman }\end{array}$ \\
\hline JooYoungJu & 5 & Ewha womans university, Seoul, Republic of Korea \\
\hline M. Al-Emran & 5 & $\begin{array}{l}\text { Faculty of Computer Systems and Software Engineering, Universiti Malaysia Pa- } \\
\text { hang, Pahang, Malaysia }\end{array}$ \\
\hline
\end{tabular}

Considering only the address of the first author, the papers are from 64 countries. There are 15 countries that are responsible for at least ten papers. These 15 countries represent $70 \%$ of our 450 papers (Fig 4. Countries with atleast 10 papers). Malaysia (54), USA (32), South Korea (30), Spain (28), Taiwan (26), UK (23), China (22), Australia (20), Indonesia (15), Canada (13), Iran (12), Turkey (12), Brazil (10), India (10) and Oman (10).

Continuing to analyse only by the first author, we find that there are 5 organizations that stand out for the amount of articles: published three of these organizations are from Malaysia, one from Oman and the other from the Republic of Korea (Organizations with more references).

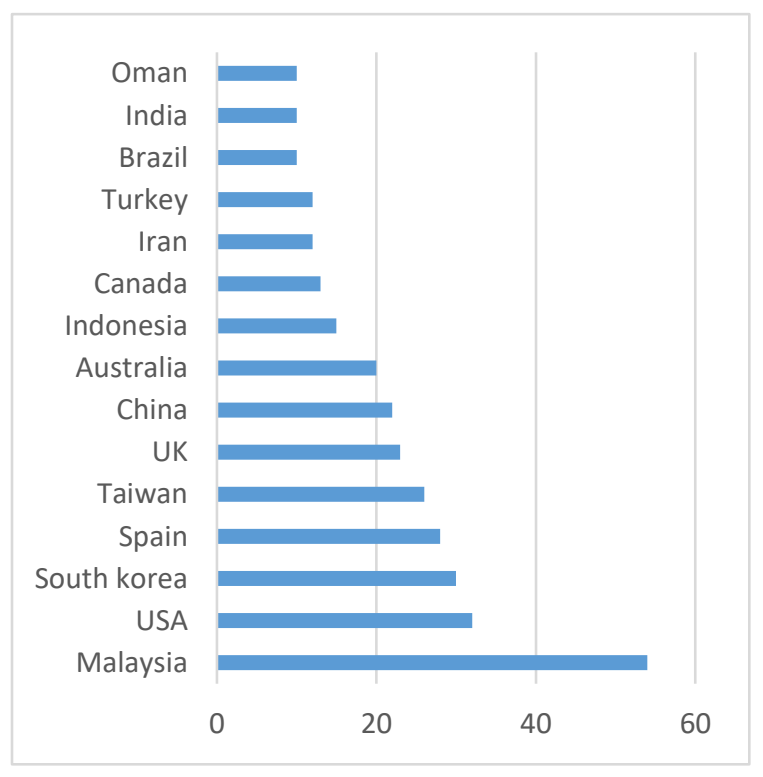

Fig. 5. Countries with at least 10 papers. 


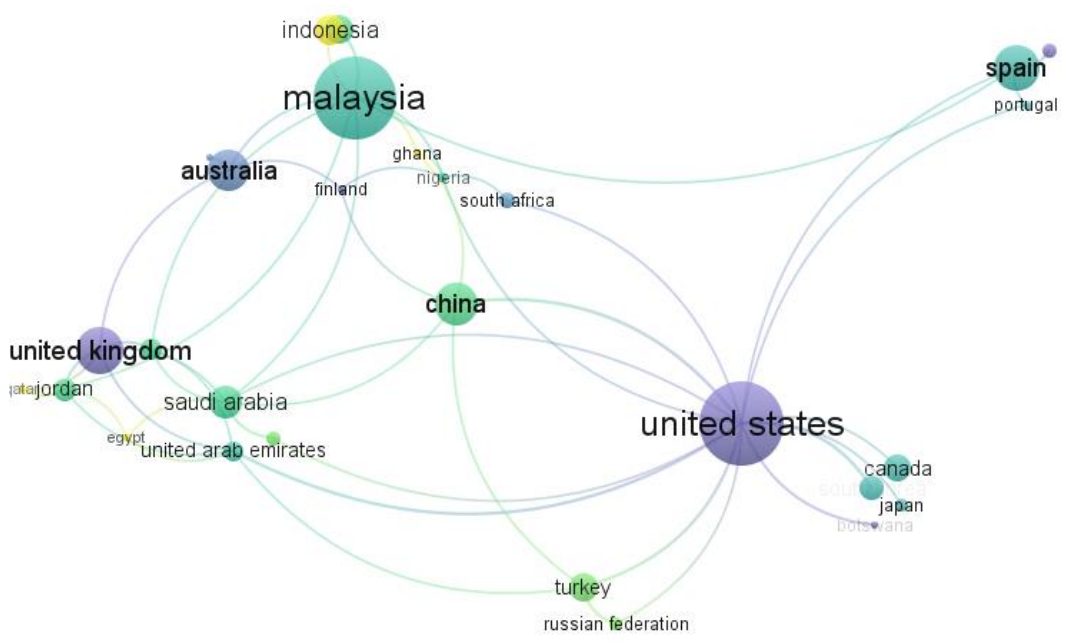

Fig. 6. Network visualization, Countries

Table 3. Organizations with more references

Organization

Communication and Information Research Center, Sultan Qaboos University, Oman

Department of Curriculum and Instruction, Faculty of Education, University of Malaya, Malaysia

Ewha womans university, Seoul, Republic of Korea

Faculty of Computer and Mathematical Sciences, Universiti Teknologi MARA, Selangor, Malaysia

School of Distance Education, Universiti Sains Malaysia, Penang, Malaysia

Since we had not used the language exclusion criterion, we can now see that English is used in $87 \%$ of the articles (

). The other languages are Spanish 6\%, Korean $4 \%$ and Portuguese $1 \%$.

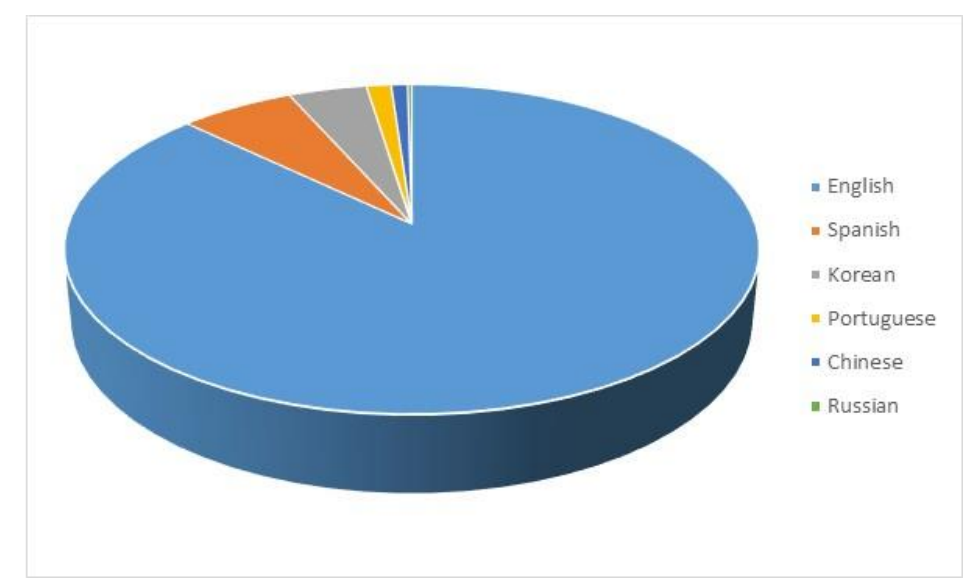

Fig. 7. Language articles 
In the following table (Most cited papers) we list top ten more cited papers.

Table 4. Most cited papers

\begin{tabular}{|c|c|c|c|c|}
\hline Author & Year & Title & Journal & Times \\
\hline Motiwalla, L.F & 2007 & $\begin{array}{l}\text { Mobile learning: A framework and evalua- } \\
\text { tion }\end{array}$ & $\begin{array}{l}\text { Computers and Educa- } \\
\text { tion }\end{array}$ & 498 \\
\hline Evans, C & 2008 & $\begin{array}{l}\text { The effectiveness of m-learning in the form } \\
\text { of podcast revision lectures in higher educa- } \\
\text { tion }\end{array}$ & $\begin{array}{l}\text { Computers and Educa- } \\
\text { tion }\end{array}$ & 389 \\
\hline $\begin{array}{l}\text { Cheon, J., Lee, S., } \\
\text { Crooks, S.M., Song, J }\end{array}$ & 2012 & $\begin{array}{l}\text { An investigation of mobile learning readi- } \\
\text { ness in higher education based on the theory } \\
\text { of planned behavior }\end{array}$ & $\begin{array}{l}\text { Computers and Educa- } \\
\text { tion }\end{array}$ & 315 \\
\hline Park, Y & 2011 & $\begin{array}{l}\text { A pedagogical framework for mobile learn- } \\
\text { ing: Categorizing educational applications of } \\
\text { mobile technologies into four types }\end{array}$ & $\begin{array}{l}\text { International Review of } \\
\text { Research in Open and } \\
\text { Distance Learning }\end{array}$ & 313 \\
\hline $\begin{array}{l}\text { Kearney, M., Schuck, } \\
\text { S., Burden, K., Aubus- } \\
\text { son, P }\end{array}$ & 2012 & $\begin{array}{l}\text { Viewing mobile learning from a pedagogical } \\
\text { perspective }\end{array}$ & $\begin{array}{l}\text { Research in Learning } \\
\text { Technology }\end{array}$ & 242 \\
\hline $\begin{array}{l}\text { El-Hussein, M.O.M., } \\
\text { Cronje, J.C }\end{array}$ & 2010 & $\begin{array}{l}\text { Defining mobile learning in the higher edu- } \\
\text { cation landscape }\end{array}$ & $\begin{array}{l}\text { Educational Technology } \\
\text { and Society }\end{array}$ & 231 \\
\hline $\begin{array}{l}\text { Martin, F., Ertzberger, } \\
\mathrm{J}\end{array}$ & 2013 & $\begin{array}{l}\text { Here and now mobile learning: An experi- } \\
\text { mental study on the use of mobile technol- } \\
\text { ogy }\end{array}$ & $\begin{array}{l}\text { Computers and Educa- } \\
\text { tion }\end{array}$ & 226 \\
\hline $\begin{array}{l}\text { Wang, M., Shen, R., } \\
\text { Novak, D., Pan, X }\end{array}$ & 2009 & $\begin{array}{l}\text { The impact of mobile learning on students' } \\
\text { learning behaviours and performance: Re- } \\
\text { port from a large blended classroom }\end{array}$ & $\begin{array}{l}\text { British Journal of Educa- } \\
\text { tional Technology }\end{array}$ & 178 \\
\hline $\begin{array}{l}\text { Huang, J.-H., Lin, Y.- } \\
\text { R., Chuang, S.-T }\end{array}$ & 2007 & $\begin{array}{l}\text { Elucidating user behavior of mobile learn- } \\
\text { ing: A perspective of the extended technol- } \\
\text { ogy acceptance model }\end{array}$ & Electronic Library & 162 \\
\hline $\begin{array}{l}\text { Seppälä, P., Alamäki, } \\
\text { H }\end{array}$ & & Mobile learning in teacher training & $\begin{array}{l}\text { Journal of Computer As- } \\
\text { sisted Learning }\end{array}$ & 143 \\
\hline
\end{tabular}

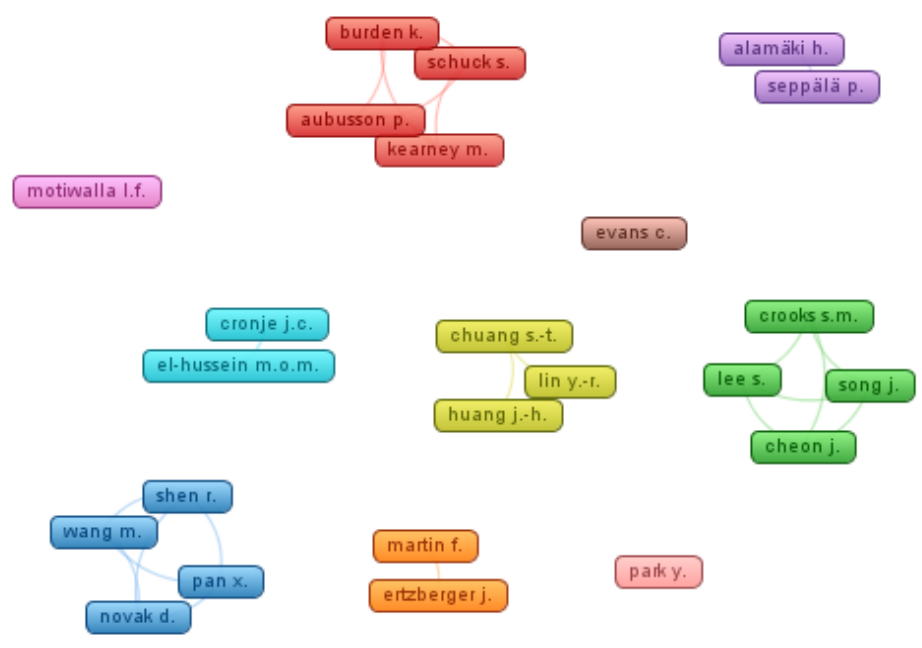

Fig. 8. Network visualization, More cited papers, Authors 


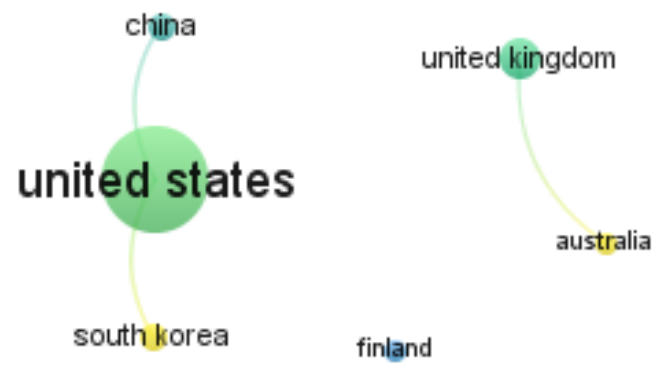

Fig. 9. Network visualization, Countries, More cited documents

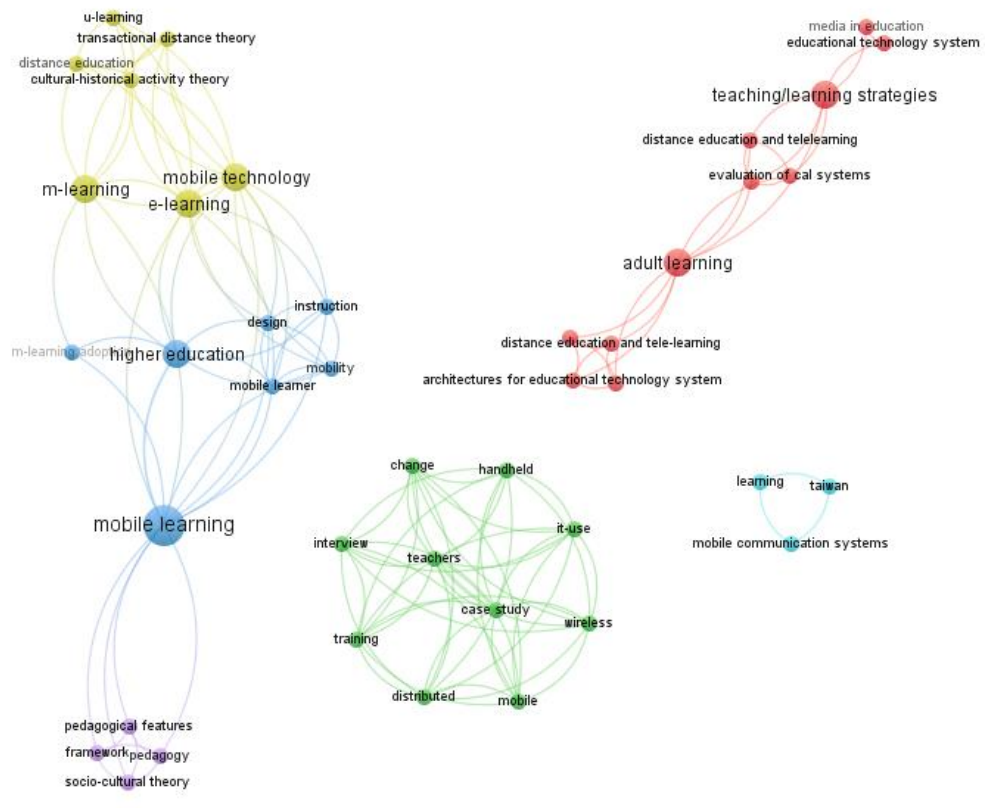

Fig. 10. Network visualization, Keywords, more cited

This list of most cited articles would not be complete if we did not list the most cited in recent years. We took into account the articles published since 2017, for propose.

H. Hamidi and A. Chavoshi; 2018; Analysis of the essential factors for the adoption of mobile learning in higher education: A case study of students of the University of Technology; Telematics and Informatics is the article with the highest annual average of citations (considering the year of publication). This paper, with a study of "what is 
the impact of the mobile phone usage in education?" provides approaches and theories on mobile learning in training. The paper aimed to evaluate the essential factors for the adoption and application of education information system that has been created by students. Furthermore, a case study from students of K. N. Toosi University in Iran was presented to indicate the performance of this method in practice. The statistical society included 300 members who were Information Technology students of Iran's K. N. Toosi University of Technology. The factors related to adoption of mobile learning in higher education were classified into seven main categories as: ease of use, trust, characters and personal qualities, context, perceived usefulness of using, behavioural intention, and culture of using a research model. From the results, one could perceive that mobile learning may be one of the promising educational technologies for development in educational environments and culture of using.

H. Crompton and D. Burke; 2018; The use of mobile learning in higher education: A systematic review; Computers and Education (123; pag.53-64) comes second in the list of annual average of citations. This systematic review provides the scholarly community with a current synthesis of mobile learning research across 2010-2016 in higher education settings regarding the purposes, outcomes, methodologies, subject matter domains, educational level, educational context, device types and geographical distribution of studies. Major findings include that the majority of the studies focused on the impact of mobile learning on student achievement. Language instruction was the most often researched subject matter domain.

R. Kaliisa and M. Picard; 2017; A systematic review on mobile learning in higher education: The African perspective; Turkish Online Journal of Educational Technology is a systematic review that compares studies published between 2010 and 2016 on mobile learning in higher education in the African context to explore the application, impact and challenges of mobile technology supported learning.

S. Hao, V. P. Dennen and L. Mei; 2017; Influential factors for mobile learning acceptance among Chinese users; Educational Technology Research and Development: examines the factors that influence mobile learning adoption among Chinese university students.

S. S. Oyelere, J. Suhonen, G. M. Wajiga and E. Sutinen; 2018; Design, development, and evaluation of a mobile learning application for computing education;Education and Information Technologies; 23; 467-495 aims to evaluate MobileEdu in a real-life learning setting. An experiment was conducted with 142 third-year undergraduate students in a Nigerian university. Besides the learning achievement of the students using MobileEdu, the study examined the impact of MobileEdu on students' attitudes toward studying in a system analysis and design course. Experimental data were collected from pre- and post quizzes, interviews, and a questionnaire was administered to students. The results of the evaluation are encouraging and showed that the MobileEdu application has a potential to improve students' learning achievements.

In the following table (Most cited papers 2017-2019) we list the most cited 20172019. 
Table 5. Most cited papers 2017-2019

\begin{tabular}{|c|c|c|c|c|}
\hline Author & Year & Title & Journal & Cited \\
\hline $\begin{array}{l}\text { H. Hamidi and A. } \\
\text { Chavoshi }\end{array}$ & 2018 & $\begin{array}{l}\text { Analysis of the essential factors for the adop- } \\
\text { tion of mobile learning in higher education: A } \\
\text { case study of students of the University of } \\
\text { Technology }\end{array}$ & Telematics and Informatics & 37 \\
\hline $\begin{array}{l}\text { H. Crompton and } \\
\text { D. Burke } \\
\end{array}$ & 2018 & $\begin{array}{l}\text { The use of mobile learning in higher educa- } \\
\text { tion: A systematic review }\end{array}$ & Computers and Education & 33 \\
\hline $\begin{array}{l}\text { R. Kaliisa and M. } \\
\text { Picard }\end{array}$ & 2017 & $\begin{array}{l}\text { A systematic review on mobile learning in } \\
\text { higher education: The African perspective }\end{array}$ & $\begin{array}{l}\text { Turkish Online Journal of } \\
\text { Educational Technology }\end{array}$ & 27 \\
\hline $\begin{array}{l}\text { S. Hao, V. P. } \\
\text { Dennen and L. } \\
\text { Mei }\end{array}$ & 2017 & $\begin{array}{l}\text { Influential factors for mobile learning ac- } \\
\text { ceptance among Chinese users }\end{array}$ & $\begin{array}{l}\text { Educational Technology } \\
\text { Research and Development }\end{array}$ & 26 \\
\hline $\begin{array}{l}\text { S. S. Oyelere, J. } \\
\text { Suhonen, G. M. } \\
\text { Wajiga and E. } \\
\text { Sutinen }\end{array}$ & 2018 & $\begin{array}{l}\text { Design, development, and evaluation of a mo- } \\
\text { bile learning application for computing educa- } \\
\text { tion }\end{array}$ & $\begin{array}{l}\text { Education and Information } \\
\text { Technologies }\end{array}$ & 21 \\
\hline $\begin{array}{l}\text { A. S. Al-Adwan, } \\
\text { A. Al-Madadha } \\
\text { and Z. Zvirzdi- } \\
\text { naite }\end{array}$ & 2018 & $\begin{array}{l}\text { Modeling students' readiness to adopt mobile } \\
\text { learning in higher education: An empirical } \\
\text { study }\end{array}$ & $\begin{array}{l}\text { International Review of } \\
\text { Research in Open and Dis- } \\
\text { tance Learning }\end{array}$ & 17 \\
\hline $\begin{array}{l}\text { Kim, H.-J., Lee, } \\
\text { J.-M., Rha, J.-Y. }\end{array}$ & 2017 & $\begin{array}{l}\text { Understanding the role of user resistance on } \\
\text { mobile learning usage among university stu- } \\
\text { dents }\end{array}$ & d Education & 19 \\
\hline $\begin{array}{l}\text { Krull, G., Duart, } \\
\text { J.M }\end{array}$ & 2017 & $\begin{array}{l}\text { Research trends in mobile learning in higher } \\
\text { education: A systematic review of articles } \\
(2011 \text { - 2015) }\end{array}$ & $\begin{array}{l}\text { International Review of } \\
\text { Research in Open and Dis- } \\
\text { tance Learning }\end{array}$ & 18 \\
\hline $\begin{array}{l}\text { Al-Hunaiyyan, } \\
\text { A., Alhajri, R.A., } \\
\text { Al-Sharhan, S } \\
\end{array}$ & 2018 & $\begin{array}{l}\text { Perceptions and challenges of mobile learning } \\
\text { in Kuwait }\end{array}$ & $\begin{array}{l}\text { Journal of King Saud Uni- } \\
\text { versity - Computer and In- } \\
\text { formation Sciences }\end{array}$ & 16 \\
\hline $\begin{array}{l}\text { Chaka, J.G., } \\
\text { Govender, I }\end{array}$ & 2017 & $\begin{array}{l}\text { Students' perceptions and readiness towards } \\
\text { mobile learning in colleges of education: } \mathrm{A} \mathrm{Ni} \text { - } \\
\text { gerian perspective }\end{array}$ & $\begin{array}{l}\text { South African Journal of } \\
\text { Education }\end{array}$ & 14 \\
\hline
\end{tabular}

\section{$5 \quad$ Discussion and Results}

The purpose of this paper is to analyse the scientific production in mobile learning in higher education in journals indexed in Clarivate Analytics' Web of Science and Elsevier's Scopus. The sample was composed by 450 articles in total. Let us now answer the research questions:

- How has the evolution of the publication of articles in quality journals related to mobile learning in higher education been? The results obtained by bibliometric analysis showed that publication rates continue to increase: 30 articles until $2010(6.6 \%)$, 116 in 20010-2014 (25.8\%) and 304 in 2015-2019 (67.6\%).

- What are the characteristics of journals where there is a greater number of publications related to the subject? The 450 papers were published in 244 international journals. Four of the six journals that published the greatest number of articles are from the first quartile. The most common WoS subjects are Social Sciences and Computer 
Science. The most common WoS categories are Social Sciences (Education) and Social Sciences (E-Learning).

- What is the approach to m-Learning in higher education? Has it evolved over the years? Mobile Learning, m-Learning, e-Learning, Higher education and students are the most common keywords all over the years. Production until 2010 had a focus on Case Study, Classroom teaching and Collaborative learning, while after 2010 focus diverse to Computer aided instruction, Smartphones, Surveys and Technology acceptance model.

- Who publishes on the subject? Malaysia, United States of America and South Korea are the countries where the researchers who published more on the topic work.

- Where do researchers who are interested in m-Learning in higher education work? What country do they live in? Most researchers are affiliated with universities. The organizations that have published the most articles are from Malaysia, Oman and South Korea.

- What are the most cited articles? And in the last three years? Motiwalla, L.F.; 2007; Mobile learning: A framework and evaluation: Computers and Education was cited 498 times. H. Hamidi and A. Chavoshi; 2018; Analysis of the essential factors for the adoption of mobile learning in higher education: A case study of students of the University of Technology: Telematics and Informatics was cited 37 times since 2018.

Bibliometric results indicate that m-Learning in higher education is still a topic with a tendency to increase in number and quality of scientific production.

\section{References}

[1] Y. S. K. T. C. \&. S. J P. Chen, "A mobile learning system for scaffolding bird watching learning," Journal of Computer Assisted Learning, vol. 19, no. 3, p. 347-359, 2003. https:// doi.org/10.1046/j.0266-4909.2003.00036.x

[2] R. L. Wang, R. Wiesemes and C. Gibbons, "Developing digital fluency through ubiquitous mobile devices: Findings from a small-scale study," Computers \& Education, vol. 58, no. 1, 2012. https://doi.org/10.1016/j.compedu.2011.04.013

[3] D. McConatha, M. Praul and M. J. Lynch, "Mobile Learning in Higher Education: An Empirical Assessment of a New Educational Tool," Turkish Online Journal of Educational Technology, vol. 7, no. 3, pp. 15-21, 2008.

[4] N. S. Alzaza and A. R. Yaakub, "Students' Awareness and Requirements of Mobile Learning," American Journal of Economics and Business Administration, vol. 3, no. 1, pp. 19455488, 2011. https://doi.org/10.3844/ajebasp.2011.95.100

[5] B. Bannan, J. Cook and N. Pachler, "Reconceptualizing design research in the age of mobile learning," Interactive Learning Environments, vol. 24, no. 5, pp. 938-953, 216. https:// doi.org/10.1080/10494820.2015.1018911

[6] E. Baran, "A Review of Research on Mobile Learning in Teacher Education," Educational Technology \& Society, vol. 17, no. 4, p. 17-32, 2014.

[7] A. Al-Hunaiyyan, S. Al-Sharhan and R. Alhajri, "A New Mobile Learning Model in the Context of Smart Classroom Environment: A Holistic Approach," International Journal of 
Interactive Mobile Technologies, vol. 11, no. 3, pp. 39-56, 2017. https://doi.org/10.3991/ ijim.v11i3.6186

[8] O. Viberg, A. Andersson and M. Wiklund, "Designing for sustainable mobile learning - reevaluating the concepts "formal" and "informal"," Interactive Learning Environments, 2018. https://doi.org/10.1080/10494820.2018.1548488

[9] B. O'Bannon and K. Thomas, "Mobile phones in the classroom: Preservice teachers answer the call," Computers \& Education, vol. 10, no. 22, pp. 110-122, 2015. https://doi.org/10. 1016/j.compedu.2015.02.010

[10] J.-L. Hung and K. Zhang, "Examining mobile learning trends 2003-2008: a categorical meta-trend analysis using text mining techniques," Journal of Computing in Higher Education, vol. 24, no. 1, pp. 1-17, 2012. https://doi.org/10.1007/s12528-011-9044-9

[11] W. W. Y. C. C. K. H. L. C. \&. H. S. Wu, "Review of trends from mobile learning studies: A meta-analysis," Computers \& Education, vol. 59, pp. 817-827, 2012.

[12] G. Krull and J. M. Duart, "Research Trends in Mobile Learning in Higher Education: A Systematic Review of Articles (2011 -2015)," International Review of Research in Open and Distributed Learning, vol. 18, no. 7, 2017. https://doi.org/10.19173/irrodl.v18i7.2893

[13] C. Pimmera, M. Mateescub and U. Gröhbiela, "Mobile and ubiquitous learning in higher education settings. A systematic review of empirical studies," Computers in Human Behavior, vol. 63, pp. 490-501, 2016. https://doi.org/10.1016/j.chb.2016.05.057

[14] Q.-K. Fu and G.-J. Hwang, "Trends in mobile technology-supported collaborative learning: A systematic review of journal publications from 2007 to 2016," Computers \& Education, vol. 119, pp. 129-143, 2018. https://doi.org/10.1016/j.compedu.2018.01.004

[15] A. Sönmez, L. Göçmez and D. \&. A. M. Uygun, "A review of Current Studies of Mobile Learning," Journal of Educational Technology \& Online Learning, vol. 1, no. 1, pp. 13-27, 2018. https://doi.org/10.31681/jetol.378241

[16] C. Lai, "Trends of mobile learning: A review of the top 100 highly cited papers," British Journal of Educational Technology, p. 1-22, 2019.

[17] J. Merigo and J. Yang, "A bibliometric analysis of operations research and management science," Omega, vol. 73, pp. 37-48, 2017. https://doi.org/10.1016/j.omega.2016.12.004

[18] I. Zupic and T. Čater, "Bibliometric Methods in Management and Organization," Organizational Research Methods, vol. 8, no. 3, 2015. https://doi.org/10.1177/109442811 4562629

[19] M. Cobo, A. López-Herrera, E. Herrera-Viedma and H. F., "SciMAT: A new science mapping analysis software tool," Journal of the American Society for Information Science, vol. 3, no. 8, pp. 1609-1630, 2012. https://doi.org/10.1002/asi.22688

[20] G. Aparicio, T. Iturralde and A. Maseda, "Conceptual structure and perspectives on entrepreneurship education research: A bibliometric review," European Research on Management and Business Economics, vol. 5, no. 3, pp. 105-113, 2019. https://doi.org/10.1016/j. iedeen.2019.04.003

[21] A. Booth, A. Sutton and D. Papaioannou, Systematic Approaches to a Successful Literature Review, 2md ed, SAGE Publications Ltd, 2016.

[22] A. Pritchard, "Statistical Bibliography or Bibliometrics," Journal of Documentation, vol. 25, pp. 348-349, 1969.

[23] H. F. Moed, Citation Analysis in Research Evaluation, vol. 9, Springer, 2005, p. 348.

[24] S. M. R. P. Z. e. a. Bojović, "An overview of forestry journals in the period 2006-2010 as basis for ascertaining research trends," Scientometrics, vol. 8, p. 1331-1346, 2014. https://doi.org/10.1007/s11192-013-1171-9 
[25] W. G. M. H. G. e. a. Liu, "Profile of developments in biomass-based bioenergy research: a 20-year perspective," Scientometrics, vol. 99, p: 507-521, 2014. https://doi.org/10.1007/ s11192-013-1152-Z

[26] Elsevier B.V, "Scopus," 2020. [Online]. Available: https://www.scopus.com/.

[27] Scimago Lab, "Scimago Journal \& Country Rank," 2019. [Online]. Available: https://www.scimagojr.com/

\section{Author}

Sónia Rolland Sobral (Porto, 1971). Professor at Universidade Portucalense, Porto, Portugal since 1993 and currently a researcher at REMIT, Research in Economics, Management, and Information Technologies. She is Aggregate (Dr. Habil) in Information Sciences, Doctorate $(\mathrm{PhD})$ in Information Systems and Technologies, Master (MSc) in Electrical and Computer Engineering and Degree in Management Informatics. She has more than 100 scientific publications and her focus are the distance education, serious games, computer programming and higher education policies. She is addicted to sports, and seriously passionate about technology and travel.

Article submitted 2020-02-27. Resubmitted 2020-03-29. Final acceptance 2020-03-29. Final version published as submitted by the authors. 